\title{
Krzysztof Skotnicki
}

\section{Podmiot władzy państwowej w Republice Czeskiej oraz formy jej wykonywania}

http://dx.doi.org/10.18778/8088-830-2.10

Nieodzownym i najważniejszym elementem konstytucji współczesnych demokratycznych państw jest określenie w nich podmiotu władzy najwyższej. Jest to wskazanie o ile nie najważniejszej, to bez wątpienia jednej z najważniejszych, podstawowych zasad ustroju politycznego. W doktrynie nazywana jest ona zasadą suwerenności lub zwierzchnictwa, należy jednak pamiętać, że w przypadku pierwszej wyróżniane są dwa jej aspekty: wewnętrzny i zewnętrzny i tylko pierwszy z nich odnosi się do podmiotu władzy najwyższej, zaś drugi to suwerenność państwa jako podmiotu stosunków międzynarodowych ${ }^{1}$.

Konstytucyjne określenie podmiotu władzy najwyższej czynione jest na wiele sposobów, na co bez wątpienie wpływ miały i mają różne teorie, wskazujące, kto jest tym podmiotem i dlaczego ${ }^{2}$. Ich celem było zawsze zapewnienie legitymacji sprawowanej władzy, jak i jej ustabilizowanie i umocnienie. Zagadnienie władzy zwierzchniej w państwie, w szczególności jej genezy i rozwoju, jest stosunkowo szeroko omówione zarówno w polskiej, jak i w czeskiej doktrynie prawa konstytucyjnego ${ }^{3}$.

${ }^{1}$ Szerzej na temat problemu stosowanych w tym przypadku nazw, a nawet mylenia suwerenności państwa z suwerennością narodu, zob. wywody Waldemara J. Wołpiuka w pracy: J. Kuciński, W.J. Wołpiuk, Zasady ustroju politycznego państwa w Konstytucji Rzeczypospolitej Polskiej z 1997 roku, Warszawa 2012, s. 141.

${ }^{2}$ Bogusław Banaszak, modyfikując i rozszerzając pogląd Leona Duguita na te teorie, wyróżnia następujące ich grupy: 1) teorie patrymonialne, 2) teoria suwerenności ludu, 3) teorie suwerenności narodu, 4) teorie suwerenności państwa, 5) teorie suwerenności prawa, 6) teorie suwerenności organu państwowego, 7) teoria marksistowska. Zob. B. Banaszak, Prawo konstytucyjne, Nb. 211-218, wyd. VII, Warszawa 2015.

${ }^{3}$ Zob. np. J. Kuciński, W.J. Wołpiuk, Zasady ustroju politycznego..., s. 141-186; J. Baroš, Suverenita mezi křest'anstvim a právnímodernitou, „Časopis pro právní védu a praxi” 2011, č. 1. 
Celem opracowania jest przedstawienie regulacji podmiotu władzy najwyższej w Konstytucji Republiki Czeskiej z 16 grudnia 1992 r. $^{4}$ oraz przewidzianych w niej form jej wykonywania. W pewnym zakresie ukazane będą również rozwiązania występujące w przeszłości w Czechosłowacji, co wynika z faktu wyraźnego i akcentowanego przez polityków i przedstawicieli doktryny nawiązywania przez współczesne państwo czeskie do przeszłości i to nie tylko tej z okresu międzywojennego, ale i w niewielkim zakresie porównanie z rozwiązaniami polskimi.

Problematyka podmiotu władzy najwyższej uregulowana jest w art. 2 Konstytucji Republiki Czeskiej. W czeskiej literaturze przedmiotu podkreśla się, że jest to regulacja podstawowych aspektów funkcjonowania demokratycznego społeczeństwa nawiązująca do definicji demokracji sformułowanej przez 16. prezydenta USA Abrahama Lincolna w tzw. Mowie Gettysburgskiej z 1863 r., że to „rządy ludu, przez lud i dla ludzi”"5. Rządy ludu ustanowione są $\mathrm{w}$ ust. 1, zgodnie $\mathrm{z}$ którym lud jest źródłem wszelkiej władzy państwowej; jest to określenie zasady zwierzchnictwa ludu. Sprawowanie władzy przez lud wynika ze zdania po średniku w ust. 1, który ustanawia, iż odbywa się to za pośrednictwem organów władzy ustawodawczej, wykonawczej i sądowniczej, jak i ust. 2 dopuszczającego ustanowienia w ustawie konstytucyjnej możliwości jej wykonywania bez-

126 pośrednio. Wreszcie sprawowanie władzy dla ludu wyrażone jest wprost w ust. 3, w którym mowa jest o tym, że władza państwowa służy wszystkim obywatelom ${ }^{6}$.

Dalsze rozważania na temat podmiotu władzy najwyższej w Republice Czeskiej przede wszystkim wymaga odniesienia się do kwestii terminologicznej. W tradycji konstytucjonalizmu czechosłowackiego i czeskiego na jego określenie używane jest pojęcie „lid". Po raz pierwszy zostało ono użyte w Konstytucji Republiki Czechosłowackiej z 29 lutego 1920 r. $^{7}$ (§ 1 ust. 1). Następnie było powtórzone w Konstytucji Republiki Czechosłowackiej z 8 maja 1948 r. ${ }^{8}$ (art. 1 ust. 2), jak i Konstytucji Czechosłowackiej Republiki Socjalistycznej z 11 lipca 1960 r. ${ }^{9}$ (art. 2 ust. 1) oraz

${ }^{4}$ Jej tekst został ogłoszony w urzędowym organie publikacyjnym Republiki Czeskiej „Sbírka zákonů České republiky” 1993, nr 1. Polskie tłumaczenie tej konstytucji w przekładzie Marii Kruk-Jarosz zawarte jest w zbiorze: W. Staśkiewicz (red.), Konstytucje państw Unii Europejskiej, Warszawa 2011, s. 191-212.

${ }^{5}$ Zob. A. Zwoliński, Dylematy demokracji, WAM 2010.

${ }_{6}$ Zob. V.Šimíček, Uwagi 1 i 2 do art. 2, [w:] L. Bahýlová, J. Filip, P. Molek, M. Podhrázký, R. Suchánek, V. Šimíček, L. Vyhnánek, Ústava České Republik. Komentář, Praha 2010.

7 121/1920 Sb., polskie tłumaczenie w: Nowe konstytucje, przełożone pod kierunkiem J. Makowskiego, Warszawa 1925.

8 150/1948 Sb., polskie tłumaczenie w: L. Gelberg (red.), Nowe konstytucje państw europejskich, Warszawa 1948.

9 100/1960 Sb. 
w ustawie konstytucyjnej z 27 października 1968 r. o federacji czechosłowackiej ${ }^{10}$ (art. 2 ust. 2), przy czym w tych dwóch ostatnich przypadkach wskazywano, w sposób typowy dla państwa socjalistycznego, że jest to lud pracujący, co miało bardzo wyraźnie na celu wyrażenie klasowo ograniczonej koncepcji suwerenności ${ }^{11}$. Konstytucja z 1992 r., posługując się, jak już wskazywałem wcześniej, pojęciem „lid”, jest zatem zgodna z wcześniejszymi regulacjami konstytucyjnymi.

Czeskie słowo „lid" w niektórych słownikach czesko-polskich tłumaczone jest wyłącznie jako 'lud' czy 'ludzie'12. Niektóre jednak podają, że oznacza ono również 'naród”'13. Tym też należy chyba wyjaśnić, dlaczego w przekładzie Konstytucji z 1920 r. dokonanym przez J. Ostrowskiego w 1925 r. pojawia się przy tłumaczeniu treści § 1 ust. 1 pojęcie „naró$\mathrm{d}^{\prime \prime 14}$, co jest też później powtarzane $\mathrm{w}$ wielu publikacjach $\mathrm{z}$ zakresu prawa konstytucyjnego ${ }^{15}$. W literaturze przedmiotu podnosi się, że w wielu językach określenia "naród” i „lud” traktowane są jako synonimy ${ }^{16}$. Kazimierz Działocha pisze nawet, że w przypadku nauki prawa konstytucyjnego „Różnice pojęciowe, akcentowane niekiedy między tymi terminami $\mathrm{w}$ kontekście rozumienia suwerenności (np. między koncepcją zwierzchnictwa narodu i zwierzchnictwa ludu w ujęciu aktów konstytucyjnych okresu wielkiej rewolucji francuskiej), uległy z czasem zatarciu i współcześnie obydwa terminy uznawane są na oznaczenie tej samej wspólnoty ludzi, której przyznaje się charakter podmiotów władzy zwierzchniej"17.

W moim przekonaniu, w języku czeskim, a w konsekwencji również na gruncie czeskiej nauki prawa konstytucyjnego, o takiej synonimiczności mówić nie można. Najlepszym na to dowodem może być fakt, że w Preambule do Konstytucji z 1920 r. pojęcie „naród” użyte jest w odniesieniu do przyjmowanej wówczas fikcji istnienia jednolitego narodu czechosłowackiego $^{18}$. Dlatego też w odniesieniu do podmiotu władzy zwierzchniej jedynym właściwym przekładem w konstytucjach czechosłowackich czy

10 143/1968 Sb., polskie tłumaczenie w: Konstytucja Czechosłowackiej Republiki Socjalistycznej, Wrocław-Warszawa-Kraków-Gdańsk 1973.

${ }_{11}$ Zob. np. K. Działocha, Uwaga 10 do art. 4, [w:] Konstytucja Rzeczypospolitej Polskiej. Komentarz, t. I, wyd. II uzup., Warszawa 2016.

${ }^{12}$ Zob. np. K. Oliva, M. Kulošová, J.Z. Svoboda, Kapesni polsko-český, česko-polský slovník, Praha 1963, s. 529.

13 Zob. np. B. Vydra, Česko-polský slovník, Praha 1958, s. 176.

${ }_{14}$ Zob. Nowe konstytucje, s. 276.

15 Zob. np. T. Szymczak, Ustrój europejskich państw socjalistycznych, Warszawa 1988, s. 411.

${ }_{16}$ Zob. M. Gulczyński, Zasada zwierzchnictwa narodu, [w:] W. Sokolewicz (red.), Zasady podstawowe polskiej konstytucji, Warszawa 1998, s. 109.

17 Zob. K. Działocha, Uwaga 10 do art. 4.

${ }^{18}$ Zob. T. Szymczak, Ustrój..., s. 411 i przywołana tam literatura. 
też obowiązującej Konstytucji Republiki Czeskiej jest pojęcie „lud", posługiwanie się natomiast terminem „naród”, co sporadycznie zdarza się w polskiej literaturze przedmiotu, uważam dlatego za błędne ${ }^{19}$.

Wyjaśnienie treści pojęcia „lud" nie jest jednak proste, może być ono bowiem rozumiane rozmaicie. Niewątpliwie zależy to od języka, w którym ono występuje, zaś w literaturze przedmiotu w pełni zasadnie podnoszone jest również, że jego zakres jest zmienny w zależności od konkretnych systemów społeczno-politycznych ${ }^{20}$. W języku polskim ma ono wiele znaczeń. Przykładowo, „1) w znaczeniu etnograficznym [jest to - K.S.] część ludzkości, związana ze sobą pochodzeniem, językiem itp.; 2) mieszkańcy wsi, niższe klasy społ." ${ }^{21}$ Michał Arct podawał z kolei, że oznacza ono „ludzi, tłum; naród, plemię, niższe warstwy społeczeństwa, pospólstwo, gmin" ${ }^{\prime 22}$. Podobnie wyjaśniają to słowniki współczesne. Lud, to: „1. warstwa społeczeństwa utrzymująca się z pracy fizycznej; dawniej głównie ludność wiejska; 2. zbiorowisko ludzkie, tłum; 3. ludzie żyjący na tym samym obszarze, mający wspólną kulturę i język, ale niemający świadomości narodowej ani tradycji państwowej" ${ }^{23}$. Jak podkreśla Mariusz Gulczyński, używanie tego pojęcia na określenie osób stojących niżej w hierarchii społecznej zrodziło się już na początku XVI w., kiedy szlachta odnosiła je do plebsu (czyli mieszczaństwa i chłopstwa), sama określając siebie natomiast jako „naród”24. Tym też 128 w dużej mierze należy tłumaczyć znaczenie, jakie przywiązywano w Polsce w minionym okresie do kwestii terminologicznych i to pomimo tego, że Konstytucja z 1921 r. stanowiła o władzy narodu rozumianego jako ogół społeczeństwa ${ }^{25}$. W języku czeskim jest jednak inaczej, gdyż pojęcie „lud” oznacza najszersze warstwy społeczeństwa, jego ogół ${ }^{26}$, a więc nie jest odnoszone jedynie do jego części, nie może też mieć miejsce jakiekolwiek jego ograniczenie z jakichkolwiek przyczyn, takich jak np. względy polityczne, majątkowe, rasowe, narodowościowe ideowe lub inne ${ }^{27}$.

19 Pojęciem „naród” posługuje się np. Marek Bankowicz. Zob. M. Bankowicz, Systemy władzy państwowej Czechosłowacji i Czech. Studium Instytucjonalno-polityczne, Kraków 1998, s. 130.

${ }^{20}$ Zob. J. Wróblewski, Z zagadnień pojęcia i ideologii demokratycznego państwa prawnego (analiza teoretyczna), „Studia Konstytucyjne”, t. VIII, Warszawa 1990, s. 16. Zob. również J. Filip, Ústavní právo, 1, Základní pojmy a instituty. Ústavní základy ČR, Brno 1999, s. 184.

21 Zob. S. Lam (red.), Encyklopedia powszechna dla wszystkich, Warszawa 1936, s. 381.

${ }_{22}$ Zob. M. Arct, Stownik ilustrowany języka polskiego, wyd. III, Warszawa [b.r.w.], s. 316.

${ }^{23}$ http://sjp.pwn.pl/szukaj/lud.html (dostęp 22.01.2017).

${ }^{24}$ Zob. M. Gulczyński, Zasada zwierzchnictw...., s. 109.

25 Ibidem.

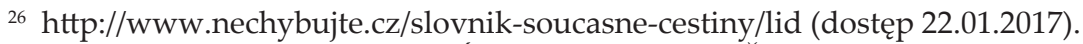

27 Zob. V. Pavlíček, J. Hřebejk, Ústava a ústavní řad České republiky. Komentář, 1. díl, Ústavní systém, Text, Dưvodová zpráva, Komentár̆, Literatura, Judikatura, Prováděcí zákony, 2. Doplněné a rozšířené vydání, Praha 1 1998, s. 58. 
Co zatem oznacza pojęcie „lud" na gruncie Konstytucji Republiki Czeskiej? Na pytanie to w czeskiej literaturze prawa konstytucyjnego najpełniej stara się udzielić odpowiedzi Jan Filip ${ }^{28}$. Jego zdaniem, można wyróżnić siedem jego znaczeń.

Po pierwsze, lud jako suweren jest źródłem władzy ustrojodawczej; jest to wyraźnie podkreślone w preambule konstytucji, w której mowa jest o tym, że jest ona przyjęta za pośrednictwem przedstawicieli wybranych w wolnych wyborach przez obywateli Republiki Czeskiej w Czechach, na Morawach i na Śląsku. Wyróżnienie to bardzo wyraźnie podkreśla polityczne legitymizowanie przez lud władzy państwowej (pouvoir constituant) ${ }^{29}$.

Po drugie, lud jako podmiot podporządkowany konstytucji, gdyż jego przedstawiciele w parlamencie nie mogą uchwalając ustawy naruszać jej, co oznacza, że nie ma on władzy absolutnej. Zwraca na to uwagę również V. Šimíček, który podkreśla, że istnieją różne środki kontrolne ${ }^{30}$.

Po trzecie, lud jako podmiot władzy reprezentowany przez organy państwa, tzn. organy władzy ustawodawczej, władzy wykonawczej i władzy sądowniczej, co wyraźnie widoczne jest w treści ślubowania składanego przez posłów, senatorów i Prezydenta, iż swój mandat/urząd będą oni „sprawować w interesie całego ludu" (art. 23 i art. 59 Konstytucji); ślubowania tej treści nie składają jednak sędziowie Sądu Konstytucyjnego i sędziowie.

Po czwarte, lud jako podmiot własności majątku narodowego, co zwłaszcza uwidaczniało się $\mathrm{w}$ dwóch ustawach konstytucyjnych przyjętych jeszcze w okresie przed rozpadem federacji ustanawiających zwrot ludowi majątku Komunistycznej Partii Czechosłowacji ${ }^{31}$ oraz zwrot majątku Socjalistycznego Związku Młodzieży ${ }^{32}$. W czeskiej literaturze przedmiotu podkreśla się dlatego, że lud jako podmiot własności majątku narodowego jest wskazany bezpośrednio przez przepisy prawa ${ }^{33}$.

Po piąte, lud jako zbiór obywateli państwa, zdaniem Jana Filipa, podkreśla to zasadę społeczeństwa obywatelskiego, które było jedyną możliwą formą rozwiązywania problemów społecznych pod koniec XX w.

Po szóste, lud jako zbiór osób posiadających (czynne) prawo wyborcze, co jest jednak pojęciem węższym od pojęcia "lud", gdyż dotyczy wyłącznie obywateli Republiki Czeskiej, którzy osiągnęli 18 lat (art. 18 ust. 3

${ }_{28}$ Zob. J. Filip, Ústavní právo..., s. 184-187.

${ }_{29}$ Zob. Uwaga 5 art. 2, [w:] L. Bahýl'ová, J. Filip, P. Molek, M. Podhrázký, R. Suchánek, V. Šimíček, L. Vyhnánek, Ústava České Republik...

${ }^{30}$ V. Šimíček, Uwaga 6 art. 2, [w:] L. Bahýlová, J. Filip, P. Molek, M. Podhrázký, R. Suchánek, V. Šimíček, L. Vyhnánek, Ústava České Republik...

${ }_{31}$ Ustawa konstytucyjna nr 496/1990 Sb.

32 Ustawa konstytucyjna nr 497/1990 Sb.

33 Zob. V. Pavlíček a kolektiv, Ústavní právo a státovéda, II. díl, Ústavní právo České republiky, 1. úplné vydání, Praha 2011, s. 378. 
Konstytucji). Jan Filip podkreśla w tym przypadku, że „W przeciwieństwie do pojęć narodu, obywatelstwa czy społeczności, lud tak w Konstytucji RCz jak i w Karcie jest przede wszystkim konstrukcją prawną opartą o: uprawnienie delegowania wykonywania władzy państwowej (art. 2 ust. 1), uprawnienie do wykonywania władzy państwowej (art. 2 ust. 2), uprawnienie do ustanawiania organów państwowych (art. 18 ust. 3), prawo do oporu (art. 23 Karty)"34. Karel Klíma mówi w tym przypadku o wąskim znaczeniu słowa „lud”, które oznacza „zbiór (sumę, zestaw) wyborców, a więc obywateli [...], którzy osiągnęli określony wiek i u których nie istnieją przeszkody w wykonywaniu prawa wyborczego"35.

Po siódme, lud w postaci państwa, tzn. Republika Czeska w stosunku do innych państw, co przejawia się m.in. w tym, że Czechy mogą zawierać umowy międzynarodowe, wstępować wspólnie z innymi państwami do federacji czy międzynarodowych stowarzyszeń (jak np. Unia Europejska), istnieć jako samodzielne suwerenne państwo, korzystać ze swoich bogactw naturalnych itp.

Konstytucja Republiki Czeskiej stanowi, iż lud jest źródłem władzy. Sformułowanie to nawiązuje do regulacji w Konstytucji z 1920 r., jak i Konstytucji z 1948 r., które stanowiły nawet, że lud jest jedynym źródłem władzy, różni się natomiast od Konstytucji z 1960 r., zgodnie z którą cała 130 władza w Czechosłowackiej Republice Socjalistycznej należy do ludu pracującego, a tym bardziej od Konstytucji z 1968 r., która stanowiła jedynie o sposobie sprawowania władzy przez lud pracujący. W czeskiej literaturze przedmiotu wskazywane jest że lud określa charakter władzy, polityki, cele ustawodawcy czy działalności rządowej bądź działalności samorządowej ${ }^{36}$.

Ze sformułowania, iż lud jest źródłem władzy, wyraźnie wynika, że lud nie jest bezpośrednio upoważniony do rządzenia i zarządzania ${ }^{37}$, nie jest bowiem podmiotem władzy, jako że Konstytucja nie stanowi, iż władza (zwierzchnia) należy do ludu ${ }^{38}$. Obowiązkiem ludu jest zatem ukonstytuowanie państwa, co przejawia się w stworzeniu systemu wartości, instytucji i procedur, którymi ma się ono rządzić.

Obowiązująca Konstytucja RCz stanowi, że lud wykonuje władzę za pośrednictwem organów władzy ustawodawczej, wykonawczej i sądowniczej (art. 2 ust. 1, zdanie po średniku), jak i otwiera możliwość uchwa-

${ }^{34}$ Zob. J. Filip, Ústavní právo..., s. 187.

35 Zob. K. Klíma, O právu ústavním, Praha 2012, s. 32.

36 Ibidem.

37 Podobnie jest w Konstytucji Rzeczypospolitej Polskiej, która akcentuje, że do narodu należy władza zwierzchnia, nie zaś rządzenie i zarządzanie. Zob. M. Gulczyński, Zasada zwierzchnictw..., s. 117.

${ }^{38} \mathrm{~W}$ polskiej literaturze przedmiotu zwraca na to uwage Marek Bankowicz. Zob. M. Bankowicz, Systemy władzy..., s. 130. 
lenia ustawy konstytucyjnej określającej, kiedy lud może wykonywać władzę państwową bezpośrednio. W tym przypadku mamy niewątpliwie do czynienia z nawiązaniem, i to nie w pełnym zakresie, jedynie do Konstytucji z 1920 r., która stanowiła: „Konstytucja postanawia za pośrednictwem jakich organów lud suwerenny nadaje sobie ustawy, przeprowadza je i wymierza sprawiedliwość" (§ 1 ust. 2). Konstytucje z 1948 i 1960 r. stanowiły bowiem, że lud (w 1960 r. i w 1968 r. lud pracujący) sprawuje (wykonuje) władzę państwową przez zgromadzenia przedstawicielskie, które są przez niego wybierane, kontrolowane i przed nim odpowiedzialne" (odpowiednio art. 4 ust. 1 i art. 2 ust. 2), natomiast zgodnie z Konstytucją z 1968 r. władza państwowa była wykonywana przez lud poprzez zgromadzenia przedstawicielskie, którymi są: Zgromadzenie Federalne, Czeska Rada Narodowa, Słowacka Rada Narodowa i rady (dosłownie - komitety) narodowe (art. 2 ust. 2).

W czeskiej doktrynie prawa konstytucyjnego w pełni zasadnie, w moim przekonaniu, wskazuje się, że w wymienieniu władzy ustawodawczej, władzy wykonawczej i władzy sądowniczej jako tych, za pośrednictwem których lud wykonuje władzę, widoczne jest wyraźne nawiązanie i zaakcentowanie monteskiuszowskiej zasady trójpodziału władzy ${ }^{39}$. Organami władzy państwowej są jednak również i inne organy, jak np. uregulowane w konstytucji Najwyższy Urząd Kontroli czy Czeski Bank Narodowy ${ }^{40}$.

Konstytucja RCz w art. 2 nawiązuje wprost do tradycyjnego rozróżnienia demokracji bezpośredniej i do demokracji pośredniej (przedstawicielskiej). Regulacja tego przepisu nie pozostawia jednak wątpliwości, że czeski ustrojodawca nie traktuje tych form jako równorzędnych bądź alternatywnych. Widoczne jest to już poprzez uregulowanie ich w różnych ustępach, wymienienie w ust. 1 demokracji pośredniej czy dopiero w ust. 2 demokracji bezpośredniej. Przede wszystkim świadczy jednak o tym to, że wykonywanie władzy państwowej przez lud może nastąpić dopiero poprzez ewentualne (użyty zwrot "może”) uchwalenie ustawy konstytucyjnej określającej, kiedy lud może wykonywać władzę państwową bezpośrednio. W piśmiennictwie podkreśla się, że wykładnia ust. 2 nie jest jednoznaczna i należy interpretować go łącznie z innymi postanowieniami konstytucji. Podkreśla się również, że wyraz „kiedy” należy rozumieć w ten sposób, „że ustawa konstytucyjna może stanowić, po spełnieniu jakich warunków, ustanowionych właściwym przepisem prawnym, lud wykonuje władzę państwową bezpośrednio" ${ }^{\prime 4}$.

${ }^{39}$ Uwaga 9 art. 2, [w:] L. Bahýlová, J. Filip, P. Molek, M. Podhrázký, R. Suchánek, V. Šimíček, L. Vyhnánek, Ústava České Republik...

40 Zob. V. Pavlíček a kolektiv, Ústavní právo a státovéda..., s. 377.

${ }^{41}$ Zob. V. Pavlíček, J. Hřebejk, Ústava..., s. 59. 
Ustrojodawca zatem nie zobowiązuje do uchwalenia takiej ustawy konstytucyjnej, lecz jedynie umożliwia jej wydanie. Jest to różnica w porównaniu $z$ porządkiem konstytucyjnym obowiązującym $\mathrm{w}$ federacji czechosłowackiej, w którym przewidziana była instytucja referendum obligatoryjnego ( $\mathrm{z}$ czego jednak $\mathrm{w}$ praktyce nigdy nie skorzystano $\mathrm{i}$ to nawet w kwestii rozpadu państwa). Obowiązująca Konstytucja RCz nie określa też form demokracji bezpośredniej, które mogą być ustanowione. Podstawową formą jest niewątpliwie referendum. Jak wiadomo, można rozróżniać wiele rodzajów referendum, przy czym podstawowym jest podział na referendum ogólnokrajowe i referendum lokalne. W Republice Czeskiej jak dotąd w przypadku referendum ogólnokrajowego uchwalono jedynie ustawę konstytucyjną z 14 listopada 2002 r. o referendum o przystąpieniu Republiki Czeskiej do Unii Europejskiej i o zmianie ustawy konstytucyjnej nr 1/1993 Sb. Konstytucja Republiki Czeskiej w brzmieniu późniejszych ustaw konstytucyjnych $^{42}$ (referendum to odbyło się w dniach 13-14 czerwca 2003 r). Natomiast $w$ przypadku referendum lokalnego pierwotnie obowiązywała ustawa z 1992 r., natomiast obecnie jest to ustawa z 11 grudnia 2003 r. o referendum lokalnym i o zmianie niektórych przepisów ${ }^{43}$, która przewiduje możliwość przeprowadzenia referendum jedynie w gminach i w głównym mieście (stolicy) Pradze oraz w ich częściach. Dopiero 29 kwietnia $2010 \mathrm{r}$.

132 została natomiast uchwalona ustawa o referendum wojewódzkim (dosłownie: krajowym) oraz o zmianie innych przepisów ${ }^{44}$.

Zgodnie z konstytucją, władza ustawodawcza należy w Republice Czeskiej do Parlamentu, który składa się z Izby Poselskiej i z Senatu (art. 15 ust. 1 i 2$)^{45}$. Władzę wykonawczą sprawuje Prezydent RCz, który jest głową państwa (art. 54) i rząd będący naczelnym organem władzy wykonawczej (art. 67). Władzą sądowniczą tworzą natomiast Sąd Konstytucyjny oraz sądy, na które składają się: Sąd Najwyższy, Najwyższy Sąd Administracyjny, sądy główne, wojewódzkie (dosłownie: krajowe) i powiatowe.

Przeprowadzona analiza pozwala stwierdzić, że uregulowanie w Republice Czeskiej podmiotu władzy państwowej oraz form jej wykonywania jest typowe dla państw demokratycznych. Władza ta należy do ludu, który przede wszystkim sprawuje ją za pośrednictwem organów władzy ustawodawczej, wykonawczej i sądowniczej. Mniejsze znaczenie ma natomiast możliwość bezpośredniego sprawowania władzy, którego formy nie są konstytucyjnie określone i przede wszystkim których uregulowanie pozostawiono uznaniu władzy ustawodawczej.

$42515 / 2002 \mathrm{Sb}$.

$4322 / 2004 \mathrm{Sb}$.

44 118/2010 Sb.

${ }_{45}$ Na temat Parlamentu zob. V. Jirásková, K. Skotnicki, Parlament Republiki Czeskiej, Warszawa 2009. 


\section{Literatura}

Arct M., Stownik ilustrowany języka polskiego, wyd. III, Warszawa [b.r.w.].

Bahýlová L., Filip J., Molek P., Podhrázký M., Suchánek R., Šimíček V., Vyhnánek L., Ústava České Republik. Komentár̆, Praha 2010.

Banaszak B., Prawo konstytucyjne, wyd. VII, Warszawa 2015.

Bankowicz M., Systemy władzy państwowej Czechosłowacji i Czech. Studium instytucjonalno-polityczne, Kraków 1998.

Baroš J., Suverenita mezi křest'anstvim a právní modernitou, „Časopis pro právní védu a praxi" 2011, č. 1.

Filip J., Ústavní právo, 1, Základní pojmy a instituty. Ústavní základy ČR, Brno 1999.

Konstytucja Rzeczypospolitej Polskiej. Komentarz, t. I, wydanie II uzup., Warszawa 2016.

Gulczyński M., Zasada zwierzchnictwa narodu, [w:] W. Sokolewicz (red.), Zasady podstawowe polskiej konstytucji, Warszawa 1998.

Jirásková V., Skotnicki K., Parlament Republiki Czeskiej, Warszawa 2009.

Klíma K., O právu ústavním, Praha 2012.

Kuciński J., Wołpiuk W.J., Zasady ustroju politycznego państwa w Konstytucji Rzeczypospolitej Polskiej z 1997 roku, Warszawa 2012.

Lam S. (red.), Encyklopedia powszechna dla wszystkich, Warszawa 1936.

Nowe konstytucje, przełożone pod kierunkiem dr. J. Makowskiego, Warszawa 1925.

Oliva K., Kulošová M., Svoboda J.Z., Kapesni polsko-český, česko-polský slovník, Praha 1963.

Pavlíček V. a kolektiv, Ústavní právo a státovéda, II. díl, Ústavní právo České republiky, 1. úplné vydání, Praha 2011.

Pavlíček V., Hřebejk J., Ústava a ústavní řad České republiky. Komentář, 1. díl, Ústavní systém, Text, Di̊vodová zpráva, Komentář, Literatura, Judikatura, Prováděcí zákony, 2. Doplněné a rozšiřené vydání, Praha 11998.

Staśkiewicz W. (red.), Konstytucje państw Unii Europejskiej, Warszawa 2011.

Szymczak T., Ustrój europejskich państw socjalistycznych, Warszawa 1988.

Vydra B., Česko-polský slovník, Praha 1958.

Wróblewski J., Z zagadnień pojęcia i ideologii demokratycznego państwa prawnego (analiza teoretyczna), „Studia Konstytucyjne”, t. VIII, Warszawa 1990.

Zwoliński A., Dylematy demokracji, WAM 2010.

\section{Akty prawne}

Konstytucja Republiki Czechosłowackiej z 29 lutego 1920 r., [w:] Nowe konstytucje, przełożone pod kierunkiem J. Makowskiego, Warszawa 1925.

Konstytucja Republiki Czechosłowackiej z 8 maja 1948 r., [w:] L. Gelberg (red.), Nowe konstytucje państw europejskich, Warszawa 1948.

Konstytucja Czechosłowackiej Republiki Socjalistycznej z 11 lipca 1960 r.

Ustawa konstytucyjna z 27 października 1968 r. o federacji czechosłowackiej, [w:] Konstytucja Czechosłowackiej Republiki Socjalistycznej, Wrocław-Warszawa-Kraków-Gdańsk 1973.

Konstytucja Republiki Czeskiej z 16 grudnia 1992 r., [w:] Konstytucje państw Unii Europejskiej, red. W. Staśkiewicz, Warszawa 2011. 
Ustawa konstytucyjna z 14 listopada 2002 r. o referendum o przystąpieniu Republiki Czeskiej do Unii Europejskiej i o zmianie ustawy konstytucyjnej nr 1/1993 Sb. Konstytucja Republiki Czeskiej w brzmieniu późniejszych ustaw konstytucyjnych.

Ustawa z 11 grudnia 2003 r. o referendum lokalnym i o zmianie niektórych przepisów.

Ustawa z 29 kwietnia 2010 r. o referendum wojewódzkim (dosłownie: krajowym) oraz o zmianie innych przepisów. 